\title{
Does Privatization Enhance or Deter Small Enterprise Formation?
}

\author{
Daniel Berkowitz* \\ Department of Economics \\ University of Pittsburgh \\ Email: dmberk@pitt.edu \\ Jonathan Holland \\ Honors College and Department of Mathematics \\ University of Pittsburgh
}

June 2001

\begin{abstract}
Small enterprises are a growth engine in post-socialist economies. We argue that privatization can either enhance or deter small enterprise formation via its impact on the local business environment. We then show that in Russia small-scale privatization deterred small enterprise formation, while large-scale privatization enhanced it.
\end{abstract}

Keywords: Small and large-scale privatization

JEL Codes: P2, L5

We thank Michael Burkart, David DeJong, Guido Friebel, John McMillan, Mitch Mokhtari and participants at the Stockholm Institute for Transition Economics workshop for comments. For financial support, Berkowitz is indebted to the National Council for Soviet and East European Research (under contract \#811-12), and Holland is indebted to the Brackenridge Foundation.

*Corresponding author: Email: dmberk@ pitt.edu; telephone: 412-648-7072; fax: 412-648-3011. Department of Economics, WWPH 4D10, Pittsburgh, PA 15260. 


\section{Does Privatization Enhance or Deter Small Enterprise Formation?}

\section{Introduction}

In post-socialist economies, there has been a rapid entry of small legally registered start-ups and spin-offs from state-owned enterprises (hereafter denoted small enterprises) into construction, trade, food establishments, commercial services and small-scale manufacturing. Kornai (1990) and McMillan (1995) argue that small enterprises are the growth engine of post-socialist economies for several reasons. Small enterprises tend to be more responsive to consumer demand than state-owned enterprises and large formerly state-owned enterprises. They also provide employment outside of the state sector, which in turn enables the state to restructure its enterprises. Small enterprises compete with the old state-owned enterprises, and this competition can generate restructuring and growth in the state sector. Small enterprise entry has been explosive in China and Poland, which are the most rapidly growing transition economies, while entry has been slow in Russia, which has contracted during the transition. ${ }^{1}$

This paper analyzes the impact of privatization on small enterprise formation in Russia. If business taxes are numerous and excessive, or if regulations are burdensome and non-transparent, or if the local governments and regulators extort bribes on a regular basis, then legal economic activity in the private sector becomes less profitable and small enterprises tend to operate in the underground economy or to exit. Privatization policy can enhance or deter small enterprise activity through its impact on the local business environment. McMillan (1995) argues that privatization can create a market enhancing local business environment if it effectively severs the political connections of formerly state-owned enterprises. Thus local governments would not have an incentive to use their tax and regulatory power over small enterprises in order to protect their formerly state-owned enterprises. Nevertheless, even if these political connections are severed, privatization does not necessarily improve the local business

\footnotetext{
${ }^{1}$ See Qian and Xu (1993) and Che and Qian (1998) for China; Jackson et al (1999) for Poland; McKinsey Global Institute (1999) and Berkowitz and DeJong (2000) for Russia; Frye and Shleifer (1997) for a comparison of Poland and Russia.
} 
environment. If a local government is weak and lacks an adequate tax base, then it will not be able to protect small enterprise property rights, and it will not be able to supply necessary public infrastructure. And, if a local government shares the enterprise tax base with other governmental agencies, then it will be forced to become part of a burdensome tax system (Shleifer and Vishny (1993); Berkowitz and Li (2000)).

In order to quantify the impact of privatization in Russia, it is useful to distinguish between small and large-scale privatization. Privatization began in 1993 when all state owned firms were allocated to the state property funds of the federal state and the regions, respectively. Local governments usually obtained control over small shops and stores, operating predominately in trade and retail services, and, for the most part, quickly sold these off for cash. The federal government obtained control over large enterprises in the manufacturing, communications, fuel, minerals, energy and heavy industry sectors. It gradually sold off ownership shares to insiders at a discount, and also allowed limited groups of outside investors to buy ownership positions using federally issued vouchers. ${ }^{2}$ Regional governments were involved in both small and large-scale privatizations.

The impact of small privatization on the local business environment is controversial. Boycko, Shleifer and Vishny (1995) argue the substantial revenues from small privatization could co-opt local governments to support market-enhancing reforms. Friebel (1995), however, shows that there was considerable insider self-dealing at the local level: business insiders and intermediate-level government insiders often colluded either to gain control of privatized assets or to block local reform efforts. Local small privatizations were typically performed on the basis of small cash deals between prospective owners and local officials. These deals were invariably corrupt because they were under the table, and the official could ask a price higher than the nominal value of the assets. This insider-self dealing could have led to a corrupt regulatory environment that deters small enterprise formation.

\footnotetext{
${ }^{2}$ These were equity claims that the Russian federal government had issued just before privatizing.
} 
The impact of the large privatization is also controversial. Black, Kraakman and Tarassova (2000) argue that the voucher privatization program led to insider self -dealing and to a generally hostile business climate including a punitive tax system, official corruption, and ubiquitous organized crime. However, Friebel (2000) argues that large privatization can also increase the transparency of the regulatory environment, which in turn enhances small enterprise formation. Large privatization can release a strong public demand for a more transparent regulatory environment because federally privatized enterprises are typically much larger than locally privatized firms, and therefore, more closely monitored by the public. The vouchers issued in the large privatization increase transparen cy because they can provide information to the public about local demand and production conditions.

Using data from sixty-nine of Russia's eighty-eight regions, we find that local privatization has deterred small enterprise formation, while the regional an $\mathrm{d}$ federal privatizations have enhanced it. One interpretation of these findings is that local privatization of small-scale industries may have led to more insider self-dealing than federal privatization, because it involved more layers of bureaucracy for corruption to infiltrate. Specifically, in local privatizations, it was relatively easy for business insiders to form alliances with local and intermediate level institutions, and thus to lobby to block the reform process at the local level, to receive go vernment credits or regulatory concessions, or to become the new official owners of the privatized business. Privatization at the federal level was conducted quite differently. First, state firms were required to re-register as corporations, with all the equity owned by the state. Next, claims to the equity were distributed to the population in the form of privatization vouchers, which could then be used to buy stock in the state corporations. While, there are many incidents of sweetheart deals in the voucher privatization, it is notable that these deals have ignited public outrage. Such public outrage is less common in the case of small privatization because there is less of a paper trail in the form of vouchers, etc., and because the firms are smaller and more costly to monitor.

Several papers use cross-national data to explain small enterprise formation in post-socialist economies. Frye and Shleifer (1997) show that small enterprises in Warsaw are more productive than their counter-parts in Moscow, because their tax and regulatory burden is much lower. Johnson, 
McMillan and Woodruff (1999) survey start-ups and spin-offs in Poland, Romania, Russia, Slovakia and the Ukraine, and find that investment in small enterprise is highest in those countries where p roperty rights are perceived to be most secure. Berkowitz and DeJong (2000) show that regions in Russia that have a highly educated and pro-reformist population tend to attract small enterprises. Qian and Xu (1993) and Che and Qian (1998) document that sma ll new enterprises are a growth engine in China because local governments have used their control and regulatory power to encourage them. Our paper explains the substantial variance in small enterprise formation across Russia on the basis of privatization policy.

\section{Data Overview}

Our data covers sixty-nine of Russia's eighty-eight regions. We have excluded regions where we could not contain a complete data series. The bulk of these regions include autonomous okrugs and krais located within Russian regions; the war-torn Chechen Republic is also excluded. Our sample spans all eleven of Russia's geographical zones.

Our measure of small enterprise formation (SMENT) is the number of legally registered enterprises per thousand citizens at the beginning of 1996, 1997, 1998 and 1999 (source, Goskomstat Rossiyi (1999), pp.280-284). ${ }^{3}$ In 1998, 21.9, 21.7, 2.9, 35.5, and 2.7 percent of workers employed in small enterprises were in industry, construction, transport, trade/food -catering and business services; the average small firm employed roughly 7.2 workers. $^{4}$

Figure 1 describes small enterprise formation between 1996 and 1999. There are five registries per thousand citizens at the beginning of 1996; registries fall to 4.5 at the beginning of 1997 and 1998 , and then increase marginally to 4.7 in the beginning of 1999 . Cross-sectional variation in small enterprises registries, however, increases over time from a standard deviation of 2.71 in 1996 to 3.37 in

\footnotetext{
${ }^{3}$ The data are available upon request from the authors.
} 
1999. Between 1996 and 1999, small enterprise registries fell by -0.16 per thousand in the average region, and registries increased in only twenty -eight out of the sixty-nine regions. Only nine regions had gains of more than one small enterprise per thousand, with Stavropol Kray, Kaliningrad Oblast and St. Petersburg exhibiting spectacular gains of 2.65, 4.63 and 9.40, respectively. Eighteen regions lost more than one small enterprise per thousand, with Kamchatka Oblast, Orenburg Oblast, Tyumen Oblast and Dagestan Republic suffering the most significant losses of $-3.13,-3.14,-5.39$ and -5.72 .

Our measure of privatization includes the number of federally, regionally and locally privatized firms at the beginning of 1994, 1995, 1996, 1997 and 1998 per thousand citizens. This is the accumulated number of privatizations commencing in $1993 .{ }^{5}$ One trend is that there is a growing regional variance (standard deviation) in privatizations over time at all levels. The number of federal privatizations per capita is much smaller than local privatizations per capita, because these federally privatized firms were typically much larger than the locally privatized firms.

A regulatory environment within a region that is transparent and limits insider self-dealing would enable small enterprises to flourish. Ceteris paribus, we would expect that regions that are more open to world markets would protect their large local enterprises less. Therefore, governments in more open regions are relatively free from the influence of inefficient large enterprises that would want the government to impo se regulations that limit small enterprise formation. We construct a regional openness index using the following available data: the per capita dollar value of regional trade per capita outside the C.I.S. for 1997 and 1998, and the per capita dollar value of regional joint venture trade volume both inside and outside the C.I.S. in 1994 and 1995. Because these trade data are highly correlated, we can

\footnotetext{
${ }^{4}$ By definition, a small enterprise is a commercial enterprise where the average employment during a yea $r$ cannot exceed 100 in transport, industry and construction; 60 in retail trade and services; 30 in wholesale trade (Goskmostat Rossiyi, 1999, p. 294).

${ }^{5}$ A limitation of this measure is that it overstates privatization levels because it does not include pr ivatized enterprises that went bankrupt or were renationalized. This, however, is not problematic because there has been very little bankruptcy and renationalization.
} 
construct an openness index using the leading principle component, which captures almost 90 percent of their variance. The variance in openness is substantial: the most open regions, Moscow, the oil rich Tyumen Oblast and St. Petersburg, are roughly 5.75, 3.75 and 1.62 standard deviations above average; the most closed regions (Bryansk, Ivanovo, Mordovian Republ ic, Tambov Oblast, Penza Oblast, Dagestan Republic, etc) are closely bunched at roughly two thirds of a standard deviation below average.

A priori, we also would expect that regions that are more supportive of market reform would tend to have a regulator y environment that is more conducive to small enterprise formation. Legally registered small businesses enhance local living standards. Since local and regional politicians must stand for reelection, their pro-reformist citizens can lobby for a transparent and pro-business regulatory environment. Warner (1999) provides empirical support for this idea: he shows that regions that voted for pro -reform candidates in the 1995 parliamentary elections tended to implement deeper microeconomic reforms. We construct an index of regional support for reform using the share of the participating voters that supported reformist candidates in the 1995 parliamentary elections, the 1996 presidential run-off, and the 1999 parliamentary elections (source: Clem and Craumer (2000)). Voting during these three episodes is highly correlated, and we construct the reformist index using the principle eigenvector, which captures 77 percent of the variance. Again, there is substantial variance across regions, with Moscow and St. Petersburg showing the most support for reform, and Kursk Oblast and the North Ossetian Republic exhibiting the most resistance.

A priori, we would also expect that regions that have a substantial natural resource endowment would have a business environment that is more hostile to small enterprises, because the focus of an economy on natural resources can lead to various forms of institutional corruption. The curse of a substantial natural resource endowment is that it encourages government and large natural resou rce firms to collude to share rents (see Sachs and Warner (1999)). We use the share of the workforce employed in the energy and fuel sector in 1985 (source: Gaddy (1996)) to measure a region's natural resource curse. It is not surprising that the oil and gas rich Siberian regions of Sakha, Sakhalin, Tyumen and Sakhalin, and the oil rich Komi Republic have the worst exposure to the resource curse. 


\section{Small Enterprises and Privatization}

In order to characterize the relationship between small enterprises an d privatization controlling for the regulatory environment, we use the regression model

$$
\begin{aligned}
\text { SMENT }_{\mathrm{t}, \mathrm{i}}= & \beta_{0}+\beta_{1} \text { FPRIV }_{\mathrm{t}-1, \mathrm{i}}+\beta_{2} \text { RPRIV }_{\mathrm{t}-1, \mathrm{i}}+\beta_{3} \text { LPRIV }_{\mathrm{t}-1, \mathrm{i}}+ \\
& \beta_{4} \text { OPEN }_{\mathrm{i}}+\beta_{5} \text { REFORM }_{\mathrm{i}}+\beta_{6} \text { RES-CURSE }_{\mathrm{i}}+\mathrm{u} .
\end{aligned}
$$

where $\mathrm{t}=1995,1996,1997$ and 1998; SMENT $_{t, i}$ denotes the total number of legally registered small enterprises at the beginning of year $t$ in region $i$, and FPRIV $_{t-1, i}, \operatorname{RPRIV}_{t-1, i}$, and $\operatorname{LPRIV}_{t-1, \mathrm{i}}$ denotes the total number of federally, regionally and locally privatized enterprises at the beginning of the previous year in region $i$. The variables $\mathrm{OPEN}_{\mathrm{i}}, \mathrm{REFORM}_{\mathrm{i}}$ and RES-CURSE $\mathrm{i}_{\mathrm{i}}$ denote region i's openness index, reformist index and resource curse, and are used to proxy for the regulatory environment. We estimate equation (1) using ordinary least squares, with a heteroskedasticity correction (White (1980)). For robustness, we can also estimate equation (1) with time dummies.

The results of the regression analysis are summarized in Table 1. The first column summarizes the regression results with time dum mies excluded. The regression model's fit is impressive: the $\mathrm{R}^{2}$ is 0.661. The proxies for the regulatory environment (openness, reformist orientation and resource curse), all have the expected sign, and all are significant at the 1-percent level. The quan titative impact of these variables is substantial: a one-standard deviation increase a region's openness and reformist orientation is associated with an additional 1.06 and 1.55 small enterprises per thousand citizens per year; a one standard deviation increase in the resource curse is associated with a 0.44 decrease.

Regarding privatization, the signs of the regression coefficients for federal and regional privatization are both positive and significant at the 1-percent level, and the sign for local privatization is negative and significant at the 5-percent level. Thus, controlling for openness, reformist orientation and 
the resource curse, federal privatization enhances small enterprise formation, while local privatization deters it. The impact of privatization, however, is relatively weaker than the impact of changes in regional openness and reformist orientation: a one standard deviation increase in federal privatization corresponds to an additional 0.838 small firms per thousand citizens per year, while a one standard deviation increase in local privatization corresponds with a decline of 0.582 .

These results are robust to the inclusion of time dummies: our estimated regression coefficients do not change substantially, and there is no sign switching. There is a mild negative time effect (significant at the 5-percent level) in 1997 and 1998. However, including these time dummies only marginally increases the $\mathrm{R}^{2}$. More formally, we test the null hypothesis that the explanatory power of our regression model without time dummies is the same as the model with time dummies. The $\mathrm{p}$-value for the likelihood ratio test statistic is 0.127 , and the null hypothesis is not rejected.

As an additional robustness check, we broadened our definition of the resource curse to include employment in the non-ferrous metal sector. We also replaced our one period privatization lag with a two period lag. The results in Table 1 are all robust to these variations.

\section{Conclusions}

It is well understood that privatization can either enhance or deter small enterprise formation via its impact on the local business environment. In the case of Russia, the large -scale privatization, which the federal government primarily implemented, enhanced small enterprise formation. However, the small privatization, which the local governments primarily organized, inhibited small enterprise formation. Black et al (2000) among others have criticized the large -scale voucher privatization for fostering the growth of corruption in Russia, which has in turn limited small enterprise formation. Our results suggest that it was the small privatization that was more problematic in this respect. 


\section{References}

Berkowitz, D. and D. DeJong, 2000, Accounting for post -soviet Russia's economic growth, University of Pittsburgh, mimeo dated June 2000, forthcoming in Regional Science and Urban Economics.

Berkowitz, D. and W. Li, 2000, Tax rights in transition economies: A tragedy of the commons? Journal of Public Economics 76, 369-397.

Boycko, M., A. Shlefier, and R. Vishny, 1995, Privatizing Russia, (MIT Press: Cambridge, MA).

Black, B., R. Kraakman, and A. Tarassova. 2000, Russian privatization and corporate governance: What went wrong? Stanford Law Review 52, 1731-1808.

Che, J. and Y. Qian, 1998, Institutional environment, community government, and corporate governance: Understanding China's township-village enterprises, Journal of Law, Economics, and Organization 14, 123.

Clem, R., and P. Craumer, 2000, Regional patterns of political preference in Russia: The December 1999 Duma elections, Post-Soviet Geography and Economics 51, 1-29.

Friebel, G., 1995, Organizational issues in the Russian trade and service privatization, Economic Systems $19,25-58$.

Friebel, G., 2000, Bureaucracies in the Russian voucher privatization, Economics of Transition 8, 37-57. 
Frye, T. and A. Shleifer, 1997, The invisible hand and the grabbing hand, American Economic Review 87, 354-358.

Gaddy, C., 1996, The price of the past (Brookings Institute, Washington, D.C.)

Goskomstat Rossiyi, 1999, Rossiyskiy statistischeskiy yezhegodnik, (Goskomstat Rossiyi, Moscow, the Russian Federation).

2000, Regiony Rossiyi. CD-ROM, Goskomstat Rossiyi: Moscow, the Russian Federation.

Jackson, J.E., J. Klich and K. Poznanska, 1999, Democratic institutions and economic reform: The Polish case, Davidson Institute, Working Paper 240.

Johnson, S., J. McMillan and C. Woodruff, 1999, Property rights, finance and entrepreneurship, mimeo dated June 22, 1999.

McMillan, J., 1995, Markets in transition, Chapter 6 of Advances in Economics and Econometrics, David M. Kreps and Kenneth F. Wallis, eds., (Cambridge University Press, Cambridge) 1997, 210-239 [Econometric Society World Congress symposium address].

Kornai, J., 1990, The road to a free economy, (W.W. Norton \& Company, New York).

McKinsey Global Institute, 1999, Russia’s economic performance (McKinsey, Moscow).

Qian, Y. and C. Xu, 1993, Why China's economic reforms differ: The M-form hierarchy and entry/expansion of the non-state sector, The Economics of Transition, 1, 135-170. 
Sachs, J. and A. Warner, 1999, The big push, natural resource booms and growth, Journal of Development Economic 59, 43-76.

Shleifer, A. and R. Vishny, 1993, Corruption, Quarterly Journal of Economics, 108, 599-617.

Warner, A., 1999, Is Economic Reform Popular at the Polls: Russia 1995?” revised mimeo dated May

1999, Harvard Institute for International Development and Center for International Development, Harvard University.

White, H., 1980, A heteroskedasticity-consistent covariance matrix estimator and direct test for heteroskedasticity, Econometrica 48, 817-838. 
Figure 1: Small Enterprises

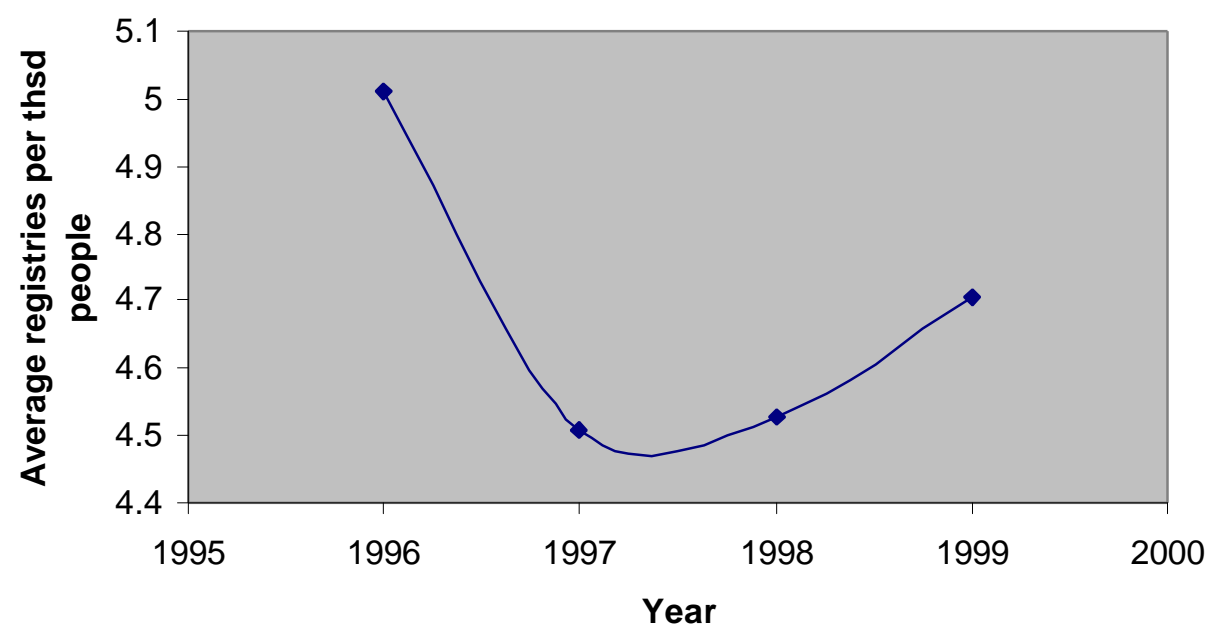


Table 1: Regressions

Dependent Variable: Small Enterprise Registries/Thousand People

\section{Explanatory Variables:}

Openness Index

Reformist Index

Resource Curse

Lagged Federal Privatization

Lagged Regional Privatization

Lagged Local Privatization

Time Dummies

1996

1997

1998

\author{
Regression Coefficients \\ (Heteroskedasticity-consistent \\ p-values) ${ }^{a}$
}

$\begin{array}{cc}0.563 & 0.532 \\ (0.000)^{* * *} & (0.000)^{* * *} \\ 1.018 & 1.020 \\ (0.000)^{* * *} & (0.000)^{* * *} \\ -5.976 & -6.010 \\ (0.001)^{* * *} & (0.001)^{* * *} \\ 11.025 & 11.083 \\ (0.000)^{* * *} & (0.000)^{* * *} \\ 7.915 & 8.157 \\ (0.006)^{* * *} & (0.005)^{* * *} \\ -2.721 & -2.595 \\ (0.033)^{* *} & (0.045)^{* *}\end{array}$

$-0.613$

$(0.034)^{* * *}$

$-0.666$

$(0.029)^{* *}$

$-0.513$

(0.109)

Likelihood ratio test: $1996=1997=1998=0$ Prob $>$ chisq. $(3)=0.127$
$\mathrm{R}^{2}$
0.661
0.667

$* * *, * *, *$ denote significance at the 1 -percent, 5-percent and 10-percent level, respectively.

${ }^{\mathrm{a}}$ White (1980). 